\title{
DNA content and MHC class II antigen expression in malignant melanoma: clinical course
}

\author{
J ZALOUDIK, ${ }^{*} \dagger$ M MOORE, ${ }^{*}$ A K GHOSH, ${ }^{*}$ Z MECHL $\ddagger$ A REJTHAR \\ From the *Department of Immunology, Paterson Institute for Cancer Research, Christie Hospital and Holt \\ Radium Institute, Manchester, and the Departments of $†$ Surgery, $\ddagger$ Medical Oncology, and $\Upsilon$ Pathology, \\ Research Institute for Clinical and Experimental Oncology, Brno, Czechoslovakia
}

SUMMARY To assess the clinical value of two comparatively new properties (DNA content and MHC class II antigen expression (HLA-DR, DP, DQ) of melanoma cells) which have been independently reported to reflect the outlook for patients with malignant melanoma, we investigated retrospectively 50 stage I nodular melanomas in two comparably homogeneous groups of 23 and 27 patients, the course of whose disease differed at five years. Flow cytometry and immunohistology were used on paraffin wax embedded archival material for the analysis of DNA ploidy and detection of class II antigens, respectively. A close association was found between class II antigen expression, detected by monoclonal antibody CR3/43 (antimonomorphic DR, DP, DQ) present in 23 of 50 $(46 \%)$ melanomas and unfavourable clinical course ( $p<0.005$, by log rank test), but no such association was found for DNA ploidy.

It is suggested that immunohistology for MHC class II antigen expression may help to predict the behaviour of nodular melanomas whereas the prognostic value of DNA ploidy is more limited. The finding that class II positive cells are found predominantly in melanomas with a substantially increased risk of metastases has implications both for concepts of tumour heterogeneity and host immunity.

Two comparatively new properties, tumour DNA ploidy and the expression of major histocompatibility complex (MHC) class II antigens on melanoma cells, have been independently reported to reflect the outlook for patients with malignant melanoma. ${ }^{1-3}$ Although they represent different biological characteristics, both are well preserved in archival histopathological material and readily accessible for retrospective analyses and clinical correlations. The investigation of these two properties in the present study was motivated by a pragmatic clinical approach to the problem of prognosis in melanoma, a disease of highly variable behaviour in which there are still no exploitable tumour markers. No mutual correlation between DNA ploidy and class II antigen expression with clinical state was anticipated, although it was considered that each variable could be independently associated with biological properties of melanomas that are inaccessible by conventional histological examination.

Abnormalities in DNA content measured by flow

Accepted for publication 19 May 1988 cytometry are a common finding in many malignant tumours. ${ }^{45}$ In two studies DNA aneuploid melanomas have been associated with a poor prognosis, ${ }^{12}$ but questions remain about whether the detection of these abnormalities is of any clinical value, or if they are associated with behavioural properties of the neoplasmas in vivo. ${ }^{6}$ Since the introduction of the method of Hedley et al, ${ }^{7}$ the analysis of nuclear DNA content by flow cytometry has been possible on paraffin wax embedded tissue with results comparable with those obtained with fresh or frozen material.

MHC class II antigens (HLA-DR, -DP, -DQ, formerly DR, SB, and DC(DS), respectively) are immunoregulatory glycoprotein molecules expressed at the cell surface and encoded by a multigene complex on the short arm of chromosome $6{ }^{89}$ They are required for co-recognition of target antigens by helper T cells, and are present on B cells, activated T cells, macrophages, and some endothelial cells; they also have a critical role in antigen presentation. MHC class II antigens are also expressed on several types of neoplasm ${ }^{10}$ in which the pattern is generally heterogeneous but their functional importance on tumour cells is not well understood. Expression on malignant melan- 
oma is constitutive or inducible. ${ }^{11-16}$ Constitutive expression may be a function of differentiation of events associated with transformation or both ${ }^{17}{ }^{18}$ and inducible expression, a response to appropriate external signals (for example, interferon gamma) in the tumour microenvironment. ${ }^{19}$

The present study was designed to compare MHC class II expression in two series of stage I nodular melanoma patients with favourable and unfavourable prognosis. It was undertaken in the knowledge that although considerable advances have been made recently in the phenotying of melanocytic lesions with monoclonal antibodies to both melanoma associated antigens and products of the MHC complex, ${ }^{20-23}$ many of the presently available reagents cannot be used on archival material for retrospective analysis of samples from patients whose clinical outcome is already known.

\section{Patients and methods}

\section{PATIENTS}

Fifty patients who had had nodular malignant melanoma treated by radical excision in the Research Institute of Clinical and Experimental Oncology, Brno, during the period 1978-81 were studied. At the time of primary resection all patients were in stage I and the stage of invasion was in each case greater than Clark's stage II and Breslow thickness $2 \cdot 0 \mathrm{~mm}$. All patients were followed up and some later underwent regional lymphadenectomy for metastases. Deaths from melanoma were confirmed by necropsy.

Patients were divided into two groups according to their different clinical courses: 23 survived for five years or more without evidence of disease and 27 died within five years, but mostly within three to four years (table 1). The groups were defined with respect to sex, male:female ratio, age, and site of the primary tumour. There were more men in the "unfavourable" group as well as more primary tumours in the head and abdomen. These trends, which accord with known facts about the distribution of the disease, were not significant.

Table 1 Clinical details of patients with stage I malignant melanoma

\begin{tabular}{lll}
\hline & $\begin{array}{l}\text { Favourable group } \\
\text { (Alive at five years } \\
\text { with no evidence } \\
\text { of disease) }\end{array}$ & $\begin{array}{l}\text { Unfavourable } \\
\text { group (Dead } \\
\text { at five years) }\end{array}$ \\
\hline No of patients & 23 & 27 \\
Mean age (years) & 54 & 56 \\
Sex (men/women) & $12 / 11$ & $19 / 8$ \\
Site of primary tumour: & 1 & 3 \\
$\quad$ Head & 9 & 13 \\
Trunk & 13 & 11 \\
\hline
\end{tabular}

FLOW CYTOMETRY

A modified method of Hedley et al was used. ${ }^{7}$ Single $30 \mu \mathrm{m}$ sections from paraffin wax embedded tissue were dewaxed by two 10 minute exchanges of xylene. The tissue was then rehydrated in decreasing concentrations $(100 \%, 95 \%, 70 \%$, and $50 \%)$ of ethanol and washed twice for 10 minutes in distilled water. The use of propidium iodide (a non-specific fluorescent dye which binds DNA and RNA) necessitated incubation of the sample for one hour in $0.1 \%$ RNAase. Disaggregation of tissue was accomplished enzymatically by incubation in $0.5 \%$ pepsin in a $37^{\circ} \mathrm{C}$ water bath at $\mathrm{pH} 1.5$ for 30 minutes followed by gentle vortex mixing or syringing to improve the release of nuclei. The suspension was then filtered through nylon mesh $(35 \mu \mathrm{m})$, centrifuged, and the pellet resuspended in staining solution $(0.05 \mathrm{mg}$ propidium iodide in $1 \mathrm{ml}$ $1 \cdot 12 \%$ sodium citrate) for analysis of DNA content on a cytofluorograph model 4800A (Biophysic System Inc, Mahopac, New Jersey, USA) with argon laser interfaced to a Hewlett Packard 4845A desk top computer. Fluorescence intensity is directly proportional to the amount of nuclear bound propidium iodide and therefore directly proportional to nuclear DNA content. In each sample 5000 nuclei were counted and DNA histograms constructed. Half peak coefficient of variance (CV) ranged from 2 to $8 \%$. Tumour samples invariably contain normal diploid stromal cells; thus all histograms contain a diploid peak that serves as an internal control. DNA ploidy was expressed by a DNA index calculated as the ratio of the mode of the aneuploid peak to the diploid peak. ${ }^{24}$

Although the number of cells in the $S+G_{2} M$ phases of the cell cycle were similar to those found by other investigators, calculation of a proliferative index from computer fitted curves was considered too inaccurate for attempted correlation with other measurements in this study.

\section{IMMUNOHISTOLOGY}

Sections $(5 \mu \mathrm{m})$ from the same blocks of paraffin wax embedded tissue were stained for MHC class II antigen and common leucocyte antigen using the alkaline phosphatase antialkaline phosphatase (APAAP) technique. ${ }^{25}$ After routine dewaxing of slides and rehydration in descending concentrations of alcohol, samples were incubated for one hour at room temperature with a 1:10 dilution of monoclonal antibody CR3/43, which reacts with a monomorphic determinant of the class II molecules DR, DP, and $\mathrm{DQ} .^{26}$ Analysis of the expression of the individual sublocus products was precluded because we had no sublocus specific antibodies capable of staining archival material. After 10 minutes washing in trometamol (Tris) buffered saline (TBS) rabbit 
antimouse antibody (1:20) was added as the second layer for 30 minutes. After a further washing in TBS the sample was incubated again for $\mathbf{3 0}$ minutes with mouse APAAP complex (1:40). Samples were developed using naphthol AS MX phosphate $2 \mathrm{mg}$, dimethylformamide $(200 \mu \mathrm{l}), 1 \mathrm{M}$ levamisole $(15 \mu \mathrm{l})$ and fast red TR salt $(10 \mathrm{mg})$ in $0.1 \mathrm{M}$ Tris, $\mathrm{pH} 8.2$ $(10 \mathrm{ml})$ for 15 minutes, counterstained in haematoxylin and mounted. Slides of class II antigens were qualitatively evaluated as positive or negative and subdivided into tumours with (a) less than $5 \%$ positive cells; (b) larger foci or areas of positivity (5-30\%); and (c) more than $30 \%$ tumour positive cells. Dako LC (anticommon leucocyte) was also used for detection of leucocytes and to distinguish the class II positivity of melanoma cells from that of tumour infiltrating leucocytes in certain cases.

\section{STATISTICAL ANALYSIS}

The significance of differences between groups was calculated by the $\chi^{2}$ test. Comparison of survival curves was by the log rank test. ${ }^{27}$

\section{Results}

FLOW CYTOMETRIC ANALYSIS

Based on DNA measurements with coefficients of variation in the range 2-8\%, DNA aneuploidy presenting as a single stemline was detectable in 31 of the 50 tumours $(62 \%)$. DNA indices ranged from 1.0 to 2.5 (median 1.5) (fig 1). Representative patterns of DNA ploidy are shown in fig 2 . Aneuploid tumours with DNA indices $1.1-1.9$ had a discernible proliferating aneuploid $S$ and $G_{2}$ population (fig 2 , lower left). In three of the 31 cases with DNA aneuploidy, two aneuploid stem lines were detected (fig 2, lower right). In the favourable group $(\mathrm{n}=23)$, seven tumours $(30 \%)$ were diploid and $16(70 \%)$ aneuploid, whereas in the unfavourable group $(n=27), 12(44 \%)$ were

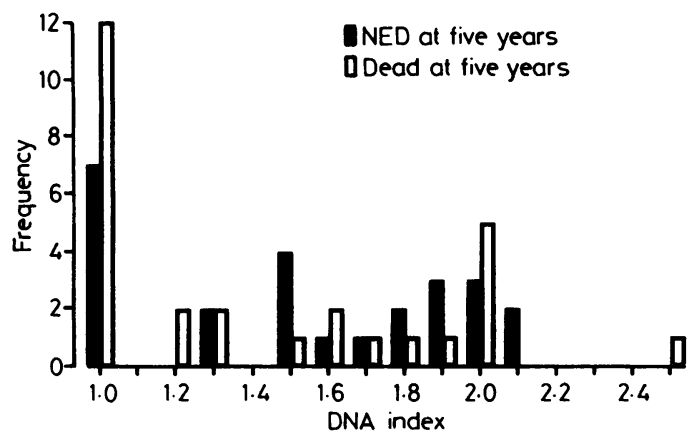

Fig 1 Frequency of DNA indexes (including two aneuploid stem lines found in 3 of 31 aneuploid tumours). diploid and $15(56 \%)$ were aneuploid (table 2). These differences are not significant. In the unfavourable group there was no association between ploidy and rapidity of recurrence (within one year; nine diploid and eight aneuploid tumours recurred; after one year three diploid and seven aneuploid tumours recurred, $p$ $=0.44$ ). There was no significant association between ploidy and survival (fig 3).

\section{IMMUNOHISTOLOGICAL DETECTION OF MHC \\ CLASS II ANTIGENS}

There were $23(46 \%)$ class II positive tumours in the whole group, of which six were classified as being type A, 10 type B, and seven type C. Significantly fewer positive cases $(n=6,26 \%)$ were found in the favourable group compared with the unfavourable group $(\mathrm{n}=17,63 \%)(\mathrm{p}=0.02)($ table 2$)$. As the monoclonal antibody CR3/43 recognises a monomorphic determinant common to the products of the three class II subloci, negative tumours were presumed to lack expression of all three antigens. Some problems were encountered in evaluating expression in the strongly pigmented areas of some tumours.

In the unfavourable group there was no difference between MHC class II expression and rapidity of recurrence (within one year, 11 class II positive tumours and six negative tumours recurred; after one year, six class II positive tumours and four negative tumours recurred; $p=0.86$ ). There was a pronounced difference in length of survival between patients with MHC class II positive and negative melanomas (fig 4) $(p<0.005)$ and within the positive group there was a tendency for patients with type $\mathrm{C}$ tumours (that is, more than $30 \%$ positive tumour cells) to fare worse than those with less than $30 \%$ positive cells.

There was no association between DNA ploidy and MHC class II expression (table 3) or between Clark's stage and class II expression (table 4), in contrast to the results reported by Brocker et al. ${ }^{21}$

\section{Discussion}

There was no correlation between the DNA content of tumours and survival among patients with malignant melanomas who underwent radical excision of their primary tumours. Although the proportion of aneuploid tumours $(62 \%)$ in the entire group is similar to other data from sequential analyses, ${ }^{28}$ the numbers must be interpreted with the knowledge that tumour heterogeneity introduces an error rate of $15-20 \%$ in estimates of DNA ploidy if, as in this study, only one sample is analysed. It must also be emphasised that flow cytometric analyses are possibly less reliable than cytogenetic estimates of tumour ploidy. DNA diploid tumours may have $10-15 \%$ of cells with abnormal DNA content that are indistinguishable by flow 

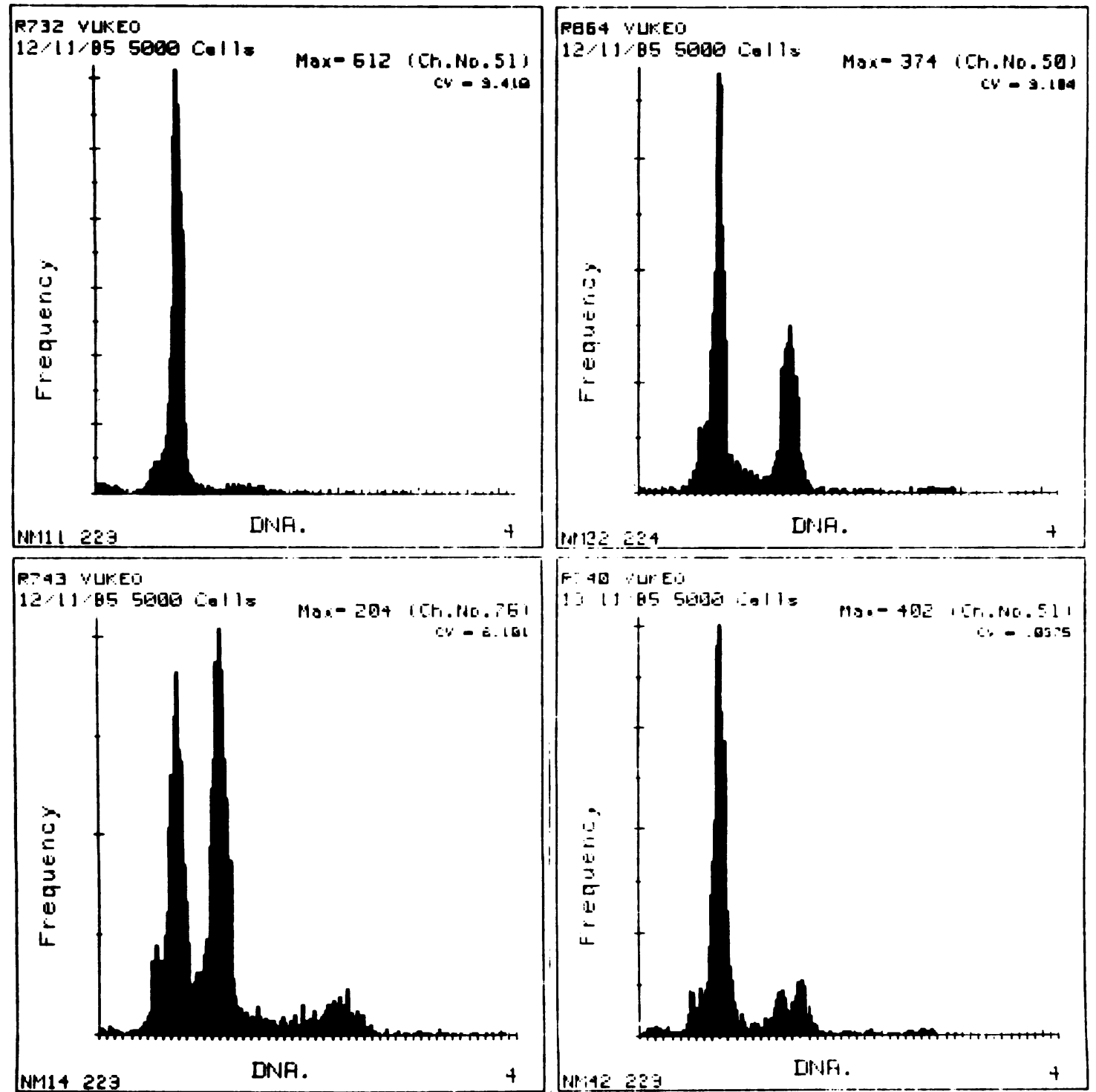

Fig 2 Patterns of DNA ploidy in malignant melanomas. Diploid (upper left); near-tetraploid (upper right); aneuploid (lower left); and multiploid (lower right).

cytometry, and the true incidence of aneuploidy may be underestimated. The precise degree of aneuploidy and of stemline heterogeneity within the tumours in this series could not, therefore, be completely ascertained.

Aneuploid tumours are considered in some studies-for example, those of colorectal cancers ${ }^{29}$ to be the more malignant; among other cancers this is not so obvious although there are some indications that they behave more aggressively. ${ }^{46}$ Earlier findings ${ }^{12}$ that the biological potential of melanocytic skin tumours is strongly linked to DNA ploidy were not confirmed in the present study of a comparison of treated patients with stage I disease, who had different clinical outcomes at five years. Our provisional conclusion, therefore, is that DNA index is of little prognostic use in primary malignant melanoma.

Considerable variability in the expression of class II 
Table 2 DNA ploidy and MHC class II state of patients with melanoma

\begin{tabular}{|c|c|c|c|}
\hline & $\begin{array}{l}\text { Favourable group } \\
\text { (Alive at five years } \\
\text { with no evidence } \\
\text { of disease) } \\
(n=23)\end{array}$ & p Value & $\begin{array}{l}\text { Unfavourable } \\
\text { group (Dead } \\
\text { at five years) } \\
(n=27)\end{array}$ \\
\hline $\begin{array}{l}\text { DNA ploidy: } \\
\text { Diploid } \\
\text { Aneuploid } \\
\text { MHC class II state: }\end{array}$ & $\begin{array}{r}7(30 \%) \\
16(70 \%)\end{array}$ & $\begin{array}{l}\text { NS } \\
\text { NS }\end{array}$ & $\begin{array}{l}12(44 \%) \\
15(56 \%)\end{array}$ \\
\hline $\begin{array}{l}\text { HLA-DR positive } \\
<5 \% \text { positive cells } \\
5-30 \% \text { positive cells } \\
>30 \% \text { positive cells } \\
\text { HLA-DR negative }\end{array}$ & $\begin{array}{l}6(26 \%) \\
2 \\
3 \\
1 \\
17(74 \%)\end{array}$ & $<0.02$ & $\begin{array}{l}17(63 \%) \\
4 \\
7 \\
6 \\
10(37 \%)\end{array}$ \\
\hline
\end{tabular}

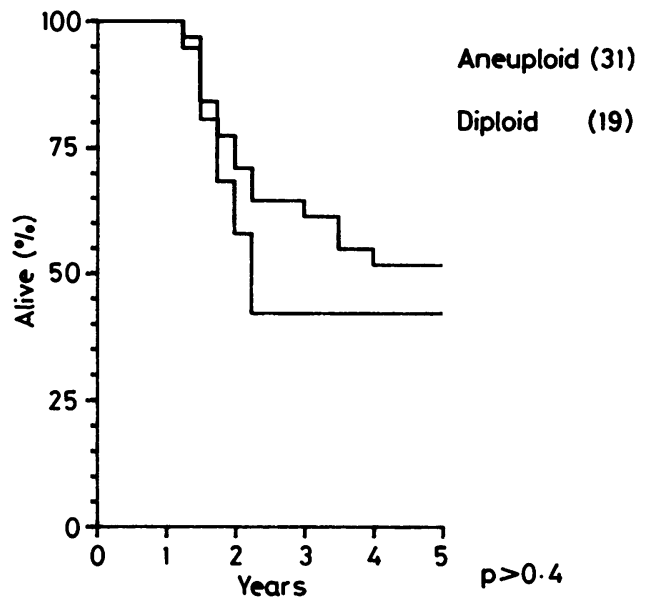

Fig 3 Association between DNA ploidy state and survival.

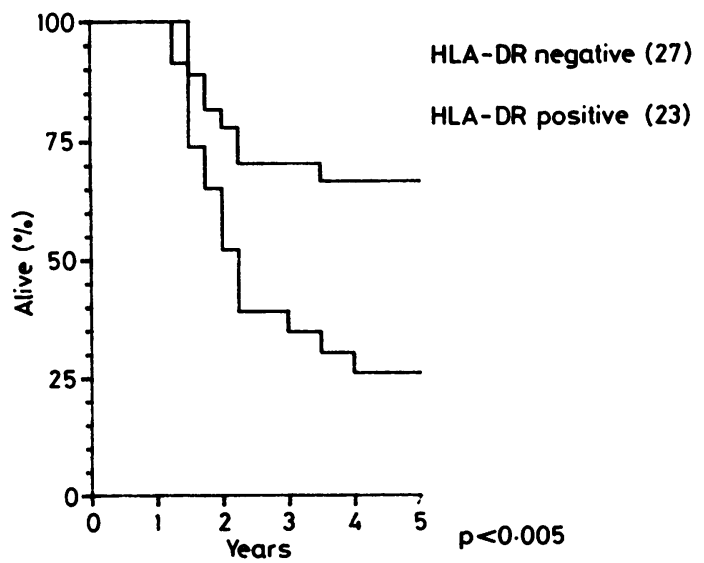

Fig 4 Association between $H L A-D R$ state and survival.
Table 3 Lack of association between DNA ploidy state and MHC class II expression

\begin{tabular}{lcll}
\hline $\begin{array}{l}\text { MHC class II } \\
\text { state }\end{array}$ & Diploid & Aneuploid & $p$ Value \\
\hline $\begin{array}{l}\text { Positive } \\
\text { Negative }\end{array}$ & 8 & 15 & NS \\
\hline
\end{tabular}

Table 4 Lack of association between Clark's stage and MHC class II expression

\begin{tabular}{|c|c|c|c|c|}
\hline \multirow{2}{*}{$\begin{array}{l}\text { MHC class II } \\
\text { status }\end{array}$} & \multicolumn{4}{|c|}{ Clark's stage } \\
\hline & $I I I$ & $I V$ & $\boldsymbol{V}$ & p Value \\
\hline $\begin{array}{l}\text { Positive } \\
\text { Negative }\end{array}$ & $\begin{array}{l}10 \\
11\end{array}$ & $\begin{array}{l}10 \\
12\end{array}$ & $\begin{array}{l}3 \\
4\end{array}$ & $\begin{array}{l}\text { NS } \\
\text { NS }\end{array}$ \\
\hline
\end{tabular}

antigens in malignant melanomas (3-90\%) has been reported; in the present study it was $46 \%$. In common with others, ${ }^{320}{ }^{23}$ we observed heterogeneity of class II expression that may to some extent explain the differences between the various studies. As an attempt at semiquantification, three patterns of staining were described. Despite the disagreement over the number of melanomas containing class II positive tumour cells, there is unanimity that class II antigens are usually present on only a subset of malignant cells⿳亠二口 within individual lesions ${ }^{203031}$; this subset coexists in vivo with the class II negative populations.

Class II antigens can be constitutively expressed on melanoma cell lines. ${ }^{12-14}$ This property is in contrast to normal melanocytes, which are class II negative both in vivo as well as in vitro unless induced by interferon gamma. ${ }^{1532}$ The distinction prompted Houghton et al $^{12}$ to postulate that the class II antigens are expressed on an early, as yet unidentified cell or cell line in the normal melanocyte lineage, and that class II positive melanomas arise from these progenitor cells. Class II products may therefore be envisaged as differentiation markers in the melanocyte pathway, defined as such because they are expressed during the earlier stages of melanocyte differentiation. ${ }^{33}$ Thus MHC class II antigens could be regarded as a component of the antigenic profile of cells with a characteristic differentiation phenotype that is determined by the point in the maturation pathway from early melanoblasts to mature melanocytes at which malignant transformation takes place.

It is evident, however, that melanomas are not "frozen" at a specific stage of differentiation and that several signals (for example, activators of cellular cyclic adenosine monophosphate) can induce them to undergo variable degrees of differentiation, with concomitant changes among other properties, in the 
expression of class II products. ${ }^{17}$ Thus class II antigens, characteristically expressed on melanomas of early or intermediate differentiation, are thought to be regulated as part of an overall differentiation programme mediated by intracellular pathways.

A second explanation for constitutive expression is that melanomas originate from class II negative precursors and that positive expression is a result of neoplastic transformation. ${ }^{34}$ Support for this concept derives from the induction of class II antigens-and other characteristics of melanomas such as augmentation of ganglioside $G_{D 3}$ concentrations and the ability to produce colonies in soft agar-in melanocytes infected with the transforming amphotropic pseudotypes of the Harvey and Kirsten murine sarcoma viruses (Ha-MSV; Ki-MSV). ${ }^{18}$ These retroviruses contain oncogenes of the ras gene family, and $10 \%$ of cultured melanomas have an activated ras gene allele (either $\mathrm{Ha}$ ras or $\mathrm{N}$ ras) and no other conclusive perturbation (rearrangement or amplification) in 15 other known oncogenes (unpublished data). Thus viral ras oncogenes initiate early transplantation events in melanocytes, and class II expression is a transformation marker in this system.

Class II antigens could also be induced on melanoma cells in response to exogeneous stimuli in the tumour microenvironment. Interferon gamma derived from activated lymphocytes within the tumour ${ }^{35}$ is one such possible mediator because of the facility with which it can induce class II antigens in certain melanoma lines, ${ }^{36}{ }^{37}$ but there are other molecular candidates. ${ }^{38}{ }^{39}$ Some of the phenotypic changes seen in primary melanomas could thus be a reflection of the interaction between the tumour and the host and as such, transient features of tumour progression.

Cumulative data suggest that the in vivo antigenic phenotype of a given melanoma is a reflection of that of several distinct tumour subsets which respond to both internal and external signals and, because of this, it is a changeable biological characteristic. The ability to respond to the various signals is likely to be associated with biological traits that differ from one subset to another. Even individual class II genes may be regulated independently ${ }^{40}{ }^{41}$; non-coordinate class II sublocus expression has been reported for other neoplasms. ${ }^{42}$

In summary, DNA content and class II expression in primary nodular malignant melanomas are independent variables. Contrary to some reports, ${ }^{43}$ DNA content as estimated by flow cytometry seems to have no direct bearing on the malignant state of the melanomas. Class II expression and its association with biological behaviour is of considerable importance and requires further analysis. Though the prognostic value of class II antigens is limited by their heterogeneity and the generally low proportion of positive cells in tumours, the disclosure that these are found predominantly in melanomas with an increased risk of metastases has implications for tumour heterogeneity and host immunity. ${ }^{21}$ To elucidate further the clinical importance of this phenomenon it would clearly be desirable to monitor their expression as a function of the progression of the disease.

We thank Mr R Swindell for statistical advice, Mr A Morris for technical assistance, Dr D Y Mason (John Radcliffe Hospital, Oxford) for the gift of CR3/43, and Miss Elaine Mercer for secretarial assistance. The study was supported by the Cancer Research Campaign. Dr J Zaloudik is a visiting fellow of the Paterson Institute.

\section{References}

1 Sondergaard K, Larsen JK, Moller U, et al. DNA ploidycharacteristics of human malignant melanoma analysed by flow-cytometry and compared with histology and clinical course. Virchows Arch (Cell Pathol) 1983;42:43-52.

2 Von Roenn JM, Kheir SM, Wolter JM, et al. Significance of DNA abnormalities in primary malignant melanoma and nevi, a retrospective flow cytometric study. Cancer Res 1986;46: 3192-5.

3 Brocker EB, Suter L, Sorg C. HLA-DR antigen expression in primary melanomas of the skin. J Invest Dermatol 1984;82: 244-7.

4 Laerum OD, Farsund T. Clinical applications of flow cytometry. A review. Cytometry 1981;2:1-13.

5 Merkel DE, Dressler LG, McGuire WL. Flow cytometry cellular DNA content, and prognosis in human malignancy. $J$ Clin Oncol 1987;5:1690-1703.

6 Friedlander ML, Hedley DW, Taylor IW. Clinical and biological significance of aneuploidy in human tumours. J Clin Pathol 1984;37:961-79.

7 Hedley DW, Friedlander ML, Taylor IW. Method for analysis of cellular DNA content of paraffin-embedded pathological material using flow cytometry. $J$ Histochem 1983;31:1333-5.

8 Bodmer WF. HLA today. Human Immunol 1986;17:490-503.

9 Bodmer WF. The HLA system: structure and function. J Clin Pathol 1987;40:948-58.

10 Natali PC, Demartino C, Quarante V. Changes in Ia antigen expression on malignant human cells. Immunogenetics 1981;12:409-13.

11 Wilson BS, Indiveri F, Pellegrino MA, et al. DR (Ia-like) antigens on human melanoma cells. J Exp Med 1979;149:658-68.

12 Houghton AN, Eisinger M, Albino AP, et al. Surface antigens of melanocytes and melanomas: markers of melanocyte differentiation and melanoma subsets. J Exp Med 1982;156:1755-66.

13 Natali PG, Cordial-Fei P, Difilippo V, et al. Ia-like antigens on freshly explanted human melanoma. Clin Immunol Immunopathol 1981;19:250-9.

14 Real FX, Houghton AN, Albino AP, et al. Surface antigens of melanomas and melanocytes defined by mouse monoclonal antibodies: specificity analysis and comparison of antigen expression in cultured cells and tissues. Cancer Res 1985;45:4401-11.

15 Houghton AN, Thomson TM, Gross D, et al. Surface antigens of melanoma and melanocytes: specificity of induction of Ia antigens by human interferon. $J$ Exp Med 1984;160:255-69.

16 Carrel S, Schmidt-Kessen A, Giuffe L. Recombinant interferon can induce the expression of HLA-DR and -DC on DRnegative melanoma cells and enhance the expression of HLA- 
ABC and tumour associated antigens. Eur $J$ Immunol 1985;15:118-23.

17 Houghton AN, Real FX, Davis LJ, et al. Phenotypic heterogeneity of melanoma. Relation to the differentiation program of melanoma cells. J Exp Med 1987;165:812-29.

18 Albino AP, Houghton AN, Eisinger M, et al. Class II histocompatibility antigen expression in human melanocytes transformed by Harvey murine sarcoma virus (Ha-MSV) and Kirsten MSV retroviruses. J Exp Med 1986;164:1710-22.

19 Herlyn M, Guerry D, Koprowski H. Recombinant-interferon induces changes in expression and shedding of antigens associated with normal human melanocytes, nevus cells and primary and metastatic melanoma cells. $J$ Immunol 1985;134:4226-30.

20 Natali PC, Bigotti A, Cavaliere R, et al. Phenotyping of lesions of melanocytic origin with monoclonal antibodies to melanomaassociated antigens and to HLA antigens. JNCI 1984;73:13-9.

21 Brocker EB, Suter L, Bruggen J, et al. Phenotypic dynamics of tumor progression in human malignant melanoma. Int J Cancer 1985;36:29-35.

22 Taramelli D, Fossati G, Mazzocchi A, et al. Classes I and II HLA and melanoma-associated antigen expression and modulation on melanoma cells isolated from primary and metastatic lesions. Cancer Res 1986;46:433-9.

23 Holzmann B, Brocker EB, Lehmann JR, et al. Tumour progression in human malignant melanoma: five stages defined by their antigenic phenotypes. Int J Cancer 1987;39:466-71.

24 Hiddeman W, Schumann J, Andreeff M, et al. Convention on nomenclature for DNA cytometry. Cytometry 1984;5:445-6.

25 Cordell JL, Falini B, Erber WN, et al. Immunoenzymatic labelling of monoclonal antibodies using immune complexes of alkaline phosphatase and monoclonal antialkaline phosphatase (APAAP complexes). J Histochem Cytochem 1984;32:219-29.

26 Sunderland CA, Naiem M, Mason DY, et al. The expression of major histocompatibility antigens by human chorionic villi. $J$ Reprod Immunol 1981;3:323-31.

27 Peto R, Pike MC, Armitage NE, et al. Design and analysis of randomised clinical trials requiring prolonged observation of each patient. II. Analysis and examples. Br J Cancer 1977; 35:1-39.

28 Wass J, Zbroja RA, Young GAR. Malignant melanoma: analysis by DNA flow cytometry. Pathology 1985;17:475-80.

29 Jones DJ, Moore M, Schofield PF. The prognostic significance of DNA ploidy in colorectal cancer: a prospective flow cytometric study. Br J Surg 1988;75:28-33.

30 Reisfeld RA. Monoclonal antibodies as probes for the molecular structure and biological function of melanoma-associated antigens. In: Sell S, ed. Monoclonal antibodies in cancer. Clifton, New Jersey: Humana Press, 1985:205-25.
31 Ruiter DJ, Bergman V, Welvaart K. Immunohistochemical analysis of malignant melanomas and naevocellular nevi with monoclonal antibodies to distinct monomorphic determinants of HLA antigens. Cancer Res 1984;44:3390-5.

32 Tsujisaki M, Igarashi M, Sakaguchi $K$, et al. Immunochemical and functional analysis of HLA class II antigens induced by recombinant immune interferon on melanocytes. J Immunol 1987;138:1310-16.

33 Albino AP, Houghton AN. Cell surface antigens of melanocytes and melanomas. Cancer Surveys 1985;4:185-211.

34 Albino AP, Le Strange R, Oliff AI, et al. Transforming ras genes from human melanoma: a manifestation of tumour heterogeneity. Nature 1984;308:69-72.

35 Kornstein MJ, Brooks JSJ, Elder DE. Immunoperoxidase localisation of lymphocyte subsets in the host response to melanoma and nevi. Cancer Res 1983;43:2749-53.

36 Basham TY, Bourgeade MF, Creasey AA. Interferon increases HLA synthesis in melanoma cells. Interferon-resistant and $\rightarrow$ sensitive cell lines. Proc Natl Acad Sci USA 1982;79:3265-9.

37 Cillo C, Mach J-P, Schreger M, et al. Antigenic heterogeneity of clones and subclones from human melanoma cell lines demonstrated by a panel of monoclonal antibodies and flow microfluorimetry analysis. Int J Cancer 1984;34:11-20.

38 Groenewegen G, De Ley M, Jeunhomme GMAA, et al. Supernatants of human leukocytes contain a mediator, different from interferon which induces expression of MHC class II antigens. $J$ Exp Med 1986;164:131-43.

39 Pfizenmaier K, Scheurich P, Schluter C, et al. Tumor necrosis factor enhances HLA-A, B, C and HLA-DR gene expression in human tumor cells. J Immunol 1987;138:975-80.

40 Pollack MS, Chin-Louie J, Moshief RD. Functional characteristics and differential expression of class II DR, DS and SB antigens of human melanoma cell lines. Hum Immunol 1984;9:75-87.

41 Anichini A, Castelli C, Sozzi G, et al. Differential susceptibility to recombinant interferon-induced HLA-DQ antigen modulation among clones from a human metastatic melanoma. $J$ Immunol 1988;140:183-91.

42 Ghosh AK, Moore M, Street AJ, et al. Expression of HLA-D subregion products on human colorectal carcinoma. Int J Cancer 1986;38:459-64.

43 Buchner T, Hiddemann W, Wormann B, et al. Differential pattern of DNA-aneuploidy in human malignancies. Pathol Res Pract 1985;179:310-17.

Requests for reprints to: Dr M Moore, Christie Hospital and Holt Radium Institute, Wilmslow Road, Manchester M20 9BX, England. 